\title{
Ligaza y-glutamylocysteiny - od molekularnych mechanizmów regulacji aktywności enzymatycznej do implikacji terapeutycznych
}

Bożena Gabryel ${ }^{1 *}$, Klaudia Bontor ${ }^{1,2}$

${ }^{1}$ Zakład Farmakologii Katedry Farmakologii, Wydział Nauk Medycznych w Katowicach, Śląski Uniwersytet Medyczny w Katowicach

'Zakład Neuroanatomii, Instytut Zoologii i Badań Biomedycznych, Uniwersytet Jagielloński, Kraków

Abstrakt

Glutation (Y-glutamylocysteinyloglicyna, GSH) jest najbardziej rozpowszechnionym tiolowym antyoksydantem wytwarzanym w cytozolu wszystkich komórek ssaków, który pełni ważną rolę ochronną przed stresem oksydacyjnym. GSH jest syntetyzowany de novo przez sekwencyjne działanie dwóch enzymów: ligazy Y-glutamylocysteiny (GCL) i syntetazy glutationowej (GS). GCL katalizuje pierwszy etap biosyntezy GSH, którego produktem jest Y-glutamylocysteina ( -GC). GCL jest heterodimerycznym enzymem zbudowanym z podjednostki katalitycznej (GCLc) i modulatorowej (GCLm), kodowanych przez dwa różne geny. Podjednostki GCL podlegają złożonej regulacji zarówno na poziomie przed-, jak i potranslacyjnym. Zmiany w ekspresji i aktywności GCL mogą zaburzać poziom GSH i homeostazy redoks. Przyczyną wielu przewlekłych schorzeń związanych ze stresem oksydacyjnym jest upośledzenie aktywności katalitycznej GCL oraz spadek stężenia GSH. Badania przedkliniczne sugerują, że podawanie egzogennej V-GC podwyższa wewnątrzkomórkowe GSH przez dostarczenie brakującego substratu i może wykazywać potencjał jako terapia uzupełniająca w chorobach związanych z deplecją GSH.

Słowa

kluczowe

glutation • y-glutamylocysteina • ligaza y-glutamylocysteiny • stres oksydacyjny

Received: 17.09.2020, Accepted: 14.04.2021

Abstract

Glutathione ( $\gamma$-glutamylcysteinylglycine, GSH) is the most abundant thiol antioxidant produced in the cytosol of all mammalian cells and plays a crucial role in protecting against oxidative stress. Glutathione is synthesized de novo by the sequential action of two enzymes: y-glutamylcysteine ligase (GCL) and glutathione synthetase (GS). GCL catalyses the first step in GSH biosynthesis, which product is $\mathrm{V}$-glutamylcysteine ( $\mathrm{V}-\mathrm{GC})$. GCL is a heterodimeric enzyme composed of catalytic (GCLc) and modulatory (GCLm) subunits encoded by two separate genes. GCL subunits are comprehensively regulated at both pre- and post-translational levels. The changes in the expression and activity of GCL can cause an imbalance in GSH levels and dysregulation of redox homeostasis. The etiology of many chronic oxidative stress-related diseases involves an impairment in the catalytic activity of GCL and decreased GSH. Preclinical studies suggest that exogenous $\mathrm{V}-\mathrm{GC}$ is able to elevate the intracellular level of GSH by providing the limiting substrate and may have potential as an adjunct treatment for diseases associated with GSH depletion.

Keywords

glutathione $\cdot \gamma$-glutamylcysteine $\bullet y$-glutamylcysteine ligase $\bullet$ oxidative stress

Received: 17.09.2020, Accepted: 14.04.2021

*Corresponding author e-mail: bgabryel@sum.edu.pl

(๔) BYr-NC-ND $\odot 2021$ Bożena Gabryel. This work is licensed under the Creative Commons Attribution-NonCommercial-NoDerivs 4.0 License. 


\section{Wstęp}

Glutation ( $($-glutamylocysteinyloglicyna, GSH) jest powszechnie występującym w przyrodzie tiolowym tripeptydem zbudowanym $\mathrm{z}$ aminokwasów: glutaminianu (Glu), cysteiny (Cys) i glicyny (Gly) [1]. Jego podstawową rolą jest utrzymanie potencjału oksydacyjno-redukcyjnego komórki, czyli fizjologicznej równowagi między procesami pro- i antyoksydacyjnymi. Równowaga oksydacyjno-redukcyjna jest niezbędna do regulacji wewnątrzkomórkowego metabolizmu, procesów wzrostu, różnicowania oraz apoptozy [2]. Glutation występuje w kilku postaciach redoksowych, a najważniejsze $z$ nich to glutation zredukowany (GSH) i glutation utleniony (GSSG). W większości komórek eukariotyczych dominuje postać zredukowana GSH (>98\%), która w warunkach stresu oksydacyjnego utleniana jest do GSSG w reakcji katalizowanej przez peroksydazę glutationową (glutathione peroxidase, GPx) [3]. Potencjał oksydacyjno-redukcyjny układu GSH/GSSG jest odpowiedzialny za antyoksydacyjne działanie glutationu, czyli neutralizację reaktywnych form tlenu i azotu (reactive oxygen and nitrogen species, RONS), nadtlenku wodoru $\left(\mathrm{H}_{2} \mathrm{O}_{2}\right)$, nadtlenków organicznych i związków elektrofilnych (detoksykacja ksenobiotyków) oraz za chelatowanie jonów metali [4]. Biologiczne funkcje glutationu są związane $z$ obecnością w jego strukturze grupy tiolowej -SH należącej do cysteiny. Dzięki wysokiej reaktywności grupy -SH biorą udział w ważnych przemianach w komórce, tj. kompleksowaniu metali, jedno- i dwuelektronowych reakcjach odwodorowania prowadzących do wytworzenia rodników tiolowych i disulfidów czy reakcjach utleniania, w których siarka przechodzi na dodatnie stopnie utlenienia $i$ powstają kwasy sulfonowe [2, 5]. Tworzenie dwusiarczków w procesie zwanym S-glutationylacją umożliwia ochronę protein przed utlenianiem ich grup -SH. Zdolność GSH do takiej odwracalnej, kowalencyjnej modyfikacji białek podkreśla jego anytyoksydacyjne i regulacyjne działanie. GSH może również regenerować oksydowane białka i ponownie je aktywować, wchodząc $w$ reakcje $\mathrm{z}$ białkowymi rodnikami tlenowymi. Bierze też udział w biosyntezie białek oraz stabilizuje ich strukturę, zapewniając prawidłowe funkcjonowanie. Ponadto GSH wpływa na biosyntezę DNA i proces proliferacji poprzez zdolnośćredukcjirybonukleotydów do deoksyrybonukleotydów [2]. GSH pełni ważną rolę w detoksykacji szkodliwych związków endogennych (tj. 4-hydroksynonenal), jak i ksenobiotyków. Z udziałem cytochromu P450 substancje endo- i egzogenne są metabolizowane do substancji elektrofilnych (faza I), które reagują $\mathrm{z}$ nukleofilową grupą $-\mathrm{SH} \mathrm{z}$ wytworzeniem S-koniugatów (faza II). Celem tej reakcji jest zmniejszenie toksyczności metabolizowanych związków oraz wzrost ich rozpuszczalności w wodzie, co ułatwia usunięcie z organizmu. Proces detoksykacji może zachodzić nieenzymatycznie (jedynie z udziałem GSH) lub być wspomagany przez S-transferazy glutationowe (glutathione S-transferase, GSTs), które znacznie przyspieszają te reakcje. Warto zaznaczyć, że GSTs są białkami aktywowanymi przez S-glutationylację, a ich największa aktywność obserwowana jest w wątrobie, która odgrywa główną rolę w biodegradacji toksycznych ksenobiotyków i związków endogennych [5].

Ważną cechą GSH jest występowanie wiązania y-peptydowego między Glu a Cys. Obecność tego nietypowego wiązania czyni GSH niewrażliwym na działanie wewnątrzkomórkowych peptydaz [4]. Jedynym białkiem zdolnym do hydrolizy wiązania $y$-peptydowego jest umiejscowiona po zewnętrznej stronie błony komórkowej Y-glutamylotranspeptydaza (Y-GT) [6]. Dzięki aktywności Y-GT, GSH uczestniczy w magazynowaniu i transporcie cysteiny, która jest aminokwasem limitującym syntezę GSH. Pozostałe aminokwasy (glutaminian i glicyna) nie odgrywają już tak ważnej roli, gdyż pozyskiwane są w wielu szlakach metabolicznych - a przez to stale dostępne w komórce [3]. Natomiast cysteina wytwarzana jest $w$ wyniku transsulfuracji z dostarczanej z pożywieniem metioniny. Jednak zdolność przekształcania metioniny do cysteiny mają tylko komórki kilku organów wewnętrznych, takich jak wątroba, nerki i śledziona. Dla pozostałych jedynym źródłem cysteiny jest jej disiarczek cystyna, występująca wyłącznie w osoczu [2]. Innym ważnym czynnikiem regulującym syntezę GSH jest aktywność ligazy (inaczej syntetazy) Y-glutamylocysteiny (GCL) [1].

\section{Synteza glutationu}

Synteza GSH odbywa się w cytozolu wszystkich typów komórek, jednak głównym miejscem wytwarzania tego związku są hepatocyty. Prawie cały zsyntetyzowany w wątrobie GSH jest wydzielany do osocza i żółci. Dlatego też jakiekolwiek zaburzenia wątrobowej syntezy GSH mają wpływ na jego ogólnoustrojową homeostaze [4].

Wewnątrzkomórkowe stężenie GSH warunkuje dynamiczna równowaga między jego syntezą, metabolizmem i transportem [3]. Istnieje kilka mechanizmów przez które komórki utrzymują wewnętrzną homeostazę GSH, tj. synteza de novo, redukcja GSSG do GSH katalizowana przez reduktazę glutationową (GR) i synteza w tzw. szlaku odzysku (salvage pathway) wykorzystującym katabolizm GSH [3]. Przemiany GSH obejmujące reakcje biosyntezy i biodegradacji po raz pierwszy opisał Alton Meister we wczesnych latach 70 . ub.w., nazwając je cyklem y-glutamylowym [7].

Synteza GSH de novo ze składowych aminokwasów to dwustopniowy proces enzymatyczny [8]. Pierwszym etapem jest katalizowana przez GCL reakcja wytworzenia wiązania y-peptydowego pomiędzy L-cysteiną i L-glutaminianem, której produktem jest dipeptyd - $\mathrm{v}$-glutamylocysteina $(\mathrm{v}-\mathrm{GC})$. 
W drugiej reakcji katalizowanej przez syntetazę glutationową (glutathione synthetase, GS) odbywa się przyłączanie glicyny do $y$-GC z utworzeniem GSH. Obie reakcje wymagają nakładów energii w postaci adenozynotrifosforanu (adenosine triphosphate, ATP) [4]. Komórkowa homeostaza GSH jest kontrolowana za pomocą nieallosterycznego hamowania wstecznego wywieranego przez GSH na aktywność GCL [8]. Nie istnieje natomiast taki mechanizm inhibicji dla GS.

Większość uzyskanego de novo GSH jest wolno rozmieszczona w cytozolu, osiągając w komórkach zwierzęcych stężenia do $10 \mathrm{mM}$. Natomiast część GSH $(\sim 10-15 \%)$ jest umiejscowiona w mitochondriach, retikulum endoplazmatycznym i macierzy jądrowej [9].

GSH może być również odzyskiwany w szlaku wykorzystującym produkty jego katabolizmu. W rozkład zewnątrzkomórkowego GSH jest zaangażowana $\mathrm{Y}$-GT, która katalizuje także degradację GSSG i różnych koniugatów glutationu. $y-G T$ przenosi resztę glutaminianową z GSH i GSH-koniugatów na inne akceptory (aminokwasy (aa) lub inne dipeptydy). Produktami reakcji są: cysteinyloglicyna (Cys-Gly), koniugaty Cys-Gly i y-glutamylo-aminokwas ( $\mathrm{Y}$-Gluaa) [2]. Następnie cysteinyloglicynę i jej koniugaty hydrolizuje dipeptydaza rozszczepiająca wiązanie między Cys a Gly [4]. Uwolnione aminokwasy oraz $\mathrm{y}$-Glu-aa są wychwytywane przez specyficzne białka transporterowe $\mathrm{i}$ przenoszone do wnętrza komórki [3]. Tam y-Glu-aa podlega jeszcze przemianie do wolnego aminokwasu i 5-oksoproliny z udziałem Y-glutamylocyklotransferazy ( $\mathrm{Y}-\mathrm{GCT})$. Cykl kończy konwersja 5-oksoproliny do glutaminianu przez 5-oksoprolinaze [9]. Odzyskane $w$ ten sposób wszystkie substraty mogą zostać wykorzystane do biosyntezy wewnątrzkomórkowego GSH [3].

\section{Ligaza Y-glutamylocysteiny (GCL)}

GCL jest heterodimerycznym kompleksem składającym się z podjednostki katalitycznej (GCLc) i modulatorowej (GCLm), których geny są umiejscowione na oddzielnych chromosomach (u człowieka 6p12 i p22.1, odpowiednio dla GCLc i GCLm) [1]. Podjednostka GCLc jest większa ( 73 $\mathrm{kDa}$ ) i zawiera miejsce aktywne odpowiedzialne za zależne od ATP utworzenie wiązania między grupą aminową cysteiny i grupą Y-karboksylową glutaminianu. Dlatego GCLc jest zdolna do samodzielnego katalizowania reakcji powstawania y-GC [10]. Natomiast GCLm ( 31 kDa) przez bezpośrednią interakcję z GLCc moduluje jej aktywność katalityczną. GCLm obniża bowiem stałą Michaelisa $(\mathrm{Km})$ dla glutaminianu i ATP, a zwiększa stałą inhibicji (Ki) dla GSH [3, 11]. Potwierdzają to badania na myszach $z$ delecją genów kodujących poszczególne podjednostki GCL. Podczas gdy knockout Gc/c był letalny już na etapie rozwoju zarodkowego, to delecja Gclm miała niewielki wpływ na przeżycie lub rozwój zwierząt $[12,13]$. Myszy pozbawione genu Gclm zachowywały bowiem zdolność syntezy ograniczonej ilości GSH (10-20\% poziomu prawidłowego).

\section{Mechanizmy regulacji GCL}

Zmiany w aktywności GCL mogą wynikać z wielopoziomowej regulacji albo jednocześnie GCLc i GCLm albo tylko GCLc [4].

\section{Regulacja transkrypcyjna}

Czynnikami transkrypcyjnymi zaangażowanymi w kontrolę transkrypcji genów GCLc i GLCm są: jądrowe czynniki

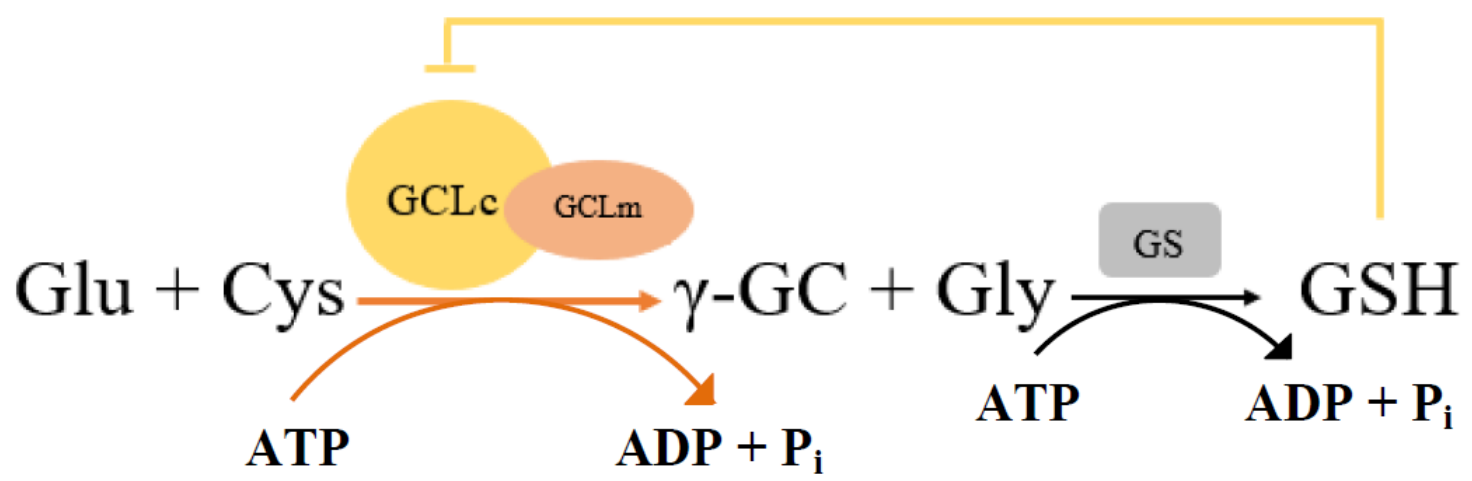

Rycina 1. Synteza glutationu: Glu - glutaminian, Cys - cysteina, ATP - adenozynotrifosforan, GCLc - podjednostka katalityczna ligazy y-glutamylocysteinowej, GCLm - podjednostka modulatorowa ligazy y-glutamylocysteinowej, y-GC - y- glutamylocysteina, Gly - glicyna, GS - syntaza glutationowa, GSH - glutation, ADP - adenozynodifosforan 
oddechowe (nuclear respiratory factor 1, 2, Nrf1, Nrf2), białka aktywatora (activating protein-1, -2, AP-1, AP-2) czynnik jądrowy NF-kB (nuclear factor KB), białka rodziny Maf, Jun, Fra, CREB (CAMP responsive element binding protein 1) $i$ inne [1]. Białka te i tworzone przez nie kompleksy wiążą się z sekwencjami regulatorowymi obu genów spełniających funkcje wzmacniaczy transkrypcji, takimi jak: element odpowiedzi antyoksydacyjnej (antioxidant response element, ARE), element odpowiedzi na metale (metal response element, MRE) oraz miejsca wiążące białko stymulujące 1 (stimulating protein-1, SP-1), AP-1, AP-2 i NF-KB [4].

Znanych jest wiele czynników regulujących GLC na poziomie transkrypcji. Zwłaszcza $w$ lekoopornych liniach nowotworowych i w warunkach stresu oksydacyjnego obserwowane jest jednoczesne zwiększenie poziomu GSH, wzrost aktywności GCL i transkrypcji genów kodujących obie jej podjednostki $[12,14]$. Wykazano, że aktywność GCL wzrasta po ekspozycji na $\mathrm{H}_{2} \mathrm{O}_{2}$ czy produkty peroksydacji lipidów, takie jak 4-hydroxynonenal (4-HNE), co świadczy o udziale tego enzymu w komórkowej odpowiedzi na stres oksydacyjny [15, 16, 17]. Skoordynowany wzrost ekspresji genów kodujących obie podjednostki GCL obserwowano po podaniu 4-HNE do hodowli szczurzych komórek nabłonka płuc L2 i ludzkich komórek nabłonka oskrzeli [18, 19]. Nasilenie transkrypcji GCLc i GCLm występowało zarówno przy poziomach 4-HNE występujących w osoczu $(0,1-1,4 \mu \mathrm{M})$, jak i przy 10-krotnie wyższych stężeniach indukujących in vivo uszkodzenia oksydacyjne. To sugeruje, że podstawowa ekspresja GCL w warunkach fizjologicznych jest regulowana przez peroksydację lipidów [19].

Konstytutywna i indukowana stresem oksydacyjnym transkrypcja obu ludzkich genów kodujących podjednostki GCL zachodzi z udziałem nie tylko białek, takich jak Nrf2, AP-1 czy NF-kB, ale także c-Myc [20]. Badania prowadzone na ludzkich komórkach czerniaka wykazały, że czynnik transkrypcyjny c-Myc reguluje ekspresję GCL przez związanie i aktywację promotorów podjednostek GCLc i GCLm. Pod wpływem $\mathrm{H}_{2} \mathrm{O}_{2}$ nasila się fosforylacja c-Myc na Ser62 przez kinazę regulowaną przez sygnały zewnątrzkomórkowe (extracellular signal-regulated kinase, ERK), która jest wymagana do przyłączenia sekwencji wzmacniających w regionach promotorowych obu genów i warunkuje odpowiedź komórkową na stres oksydacyjny [20]. Dlatego też zależna od fosforylacji c-Myc aktywacja GCL i wzrost GSH może się przyczyniać do oporności komórek nowotworowych na stres oksydacyjny [20].

Jak już wspomniano, często dochodzi do skoordynowanej indukcji dwóch podjednostek GCL - zwłaszcza przy zwiększonym wytwarzaniu RONS. Wiadomo jednak, że niektóre hormony (insulina, hydrokortyzon) lub czynniki wzrostu (TGF- $\beta 1)$ selektywnie aktywują transkrypcję tylko genu kodującego GCLc [21, 22]. Szlak sygnałowy kinazy 3-fosfatydyloinozytolu/kinazy białkowej B - Akt (phosphatidylinositol 3-kinase/protein kinase B signaling pathway, PI3K/Akt) w wielu typach komórek (hepatocytach, kardiomiocytach, śródbłonku) jest głównym mediatorem działania pobudzającego insuliny na ekspresję $\operatorname{GCLc}[5,23]$.

Innymi znanymi czynnikami wpływającymi na ekspresję tylko GCLcna poziomie transkrypcji są przeciwutleniacze, takie jak: butylowany hydroksyanizol (butylated hydroxyanisole, $\mathrm{BHA}$ ), tert-butylohydrochinon (tert-butylhydroquinone, TBH), melatonina czy kurkumina $[4,18,24,25]$.

[Ryc. 2]

Ogólnie przyjmuje się, iż w razie konieczności uruchomienia przez komórkę mechanizmów ochronnych dochodzi do szybkiego wzrostu ekspresji genu GCLc. Jednak, jeśli działanie bodźca uszkadzającego lub toksycznego przedłuża się, to ekspresja GLCc ulega deregulacji. Molekularne mechanizmy regulacji transkrypcji GLCc u gryzoni i ludzi były przedmiotem wielu badań, w których stwierdzono duży stopień ich podobieństwa. Wykazano, że region promotorowy ludzkiego genu GLCc zawiera elementy wiążące czynniki transkrypcyjne NF-kB, Sp-1, AP-1 i AP-2 oraz sekwencje nukleotydowe ARE i MRE. ARE wydaje się najważniejszym elementem do działania różnych induktorów GCLc [26]. Głównym czynnikiem transkrypcyjnym wymaganym do aktywacji ARE jest Nrf2.

W warunkach fizjologicznych Nrf2 jest umiejscowiony w cytoplazmie w postaci związanej z białkiem Keap1 (Kelch-like ECH-associated protein 1) - składnikiem kompleksu ligazy ubikwityny E3 kierującym Nrf2 do degradacji proteosomalnej [27]. Stres oksydacyjny i narażenie na działanie środków aktywujących Nrf2 powoduje przez potranslacyjną modyfikację Keap1 lub Nrf2 dysocjację wiązania między nimi [27]. To umożliwia Nrf2 uniknięcie degradacji w proteasomie i translokację do jądra komórkowego, gdzie indukuje ekspresję genów obrony antyoksydacyjnej. Zmiany w strukturze Keap1 są związane z oksydacją, glutationylacją lub nitrozylacją jednej lub kilku reszt cysteinowych. Natomiast potranslacyjne modyfikacje Nrf2 to głównie fosforylacja przez kinazy (PKC, PI3K/Akt, JNK), interakcje z innymi białkami (p-21, kaweoliną-1) oraz czynnikami epigenetycznymi. W jądrze komórkowym Nrf2 tworzy heterodimery z małymi białkami Maf (MafG, MafK, MafF) lub białkami Jun (c-Jun, Jun-D, Jun-B) i wiąże się do sekwencji nukleotydowych ARE [28]. Znaczenie szlaku Keap1/Nrf2/ARE w aktywacji GCLc potwierdzają badania, w których u myszy pozbawionych genu Nrf2 obserwowano niższy poziom ekspresji GCLc, a nadekspresja Nrf2 indukowała aktywność promotora ludzkiego genu GCLC [29]. 


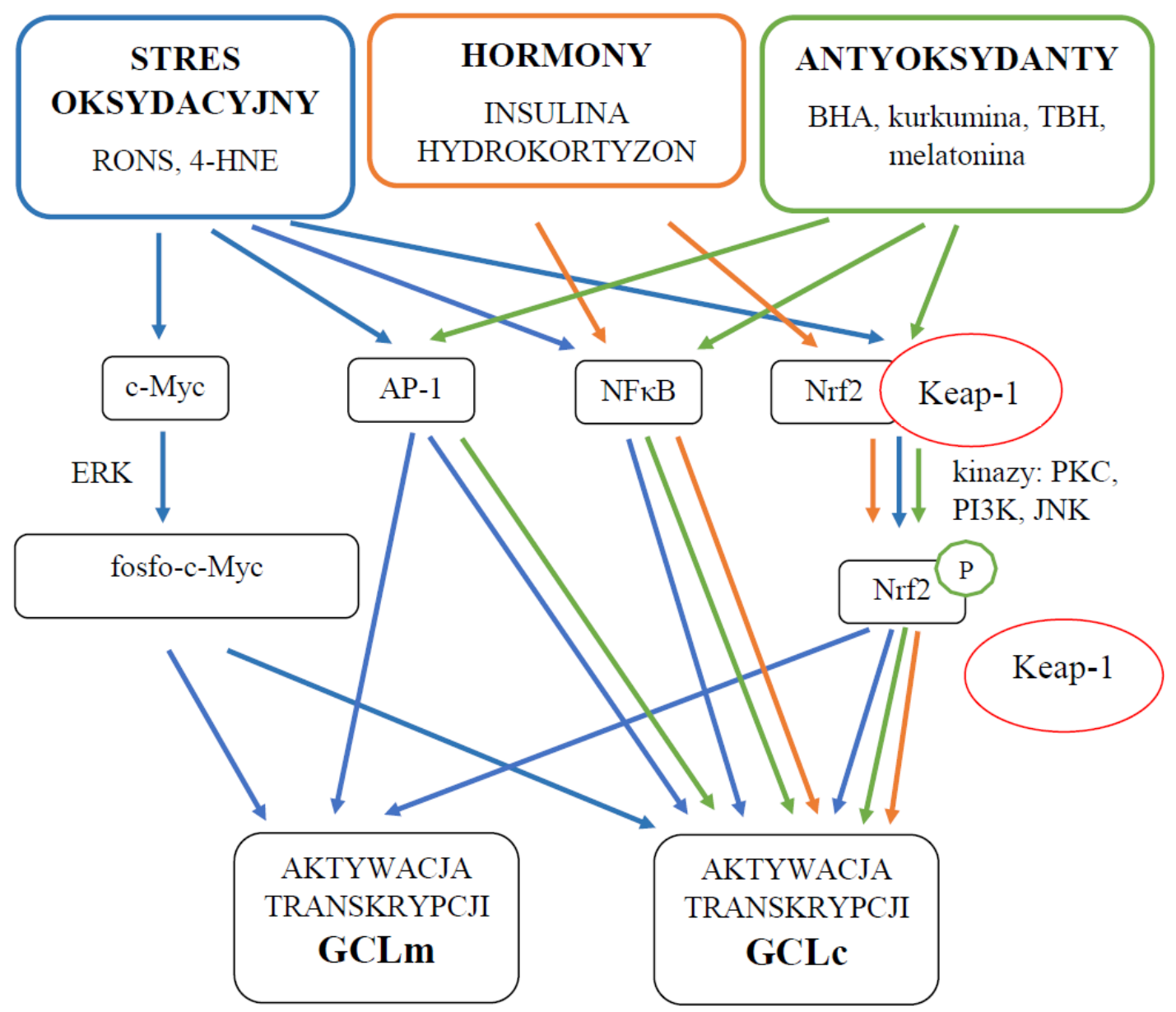

Rycina 2. Regulacja ekspresji genów kodujących podjednostkę katalityczną (GCLc) i modulatorową (GCLm) ligazy Y-glutamylocysteiny, RONS - reaktywne formy tlenu i azotu, 4-HNE - 4-hydroksynonenal, BHA - butylowany hydroksyanizol, TBH - tert-butylohydrochinon, c-Myc - gen regulatorowy i proonkogen kodujący czynniki transkrypcyjne, ERK - kinaza regulowana przez sygnały zewnątrzkomórkowe, fosfo-c-Myc - ufosforylowany c-Myc, AP-1 - białko aktywatorowe 1, NFkB - jądrowy czynnik transkrypcyjny, Nrf2 - jądrowy czynnik transkrypcyjny, Keap-1 - białko cytoszkieletu (inhibitor Nrf2), PKC - kinaza białkowa C, PI3K - kinaza-3- fosfatydyloinozytolu, JNK - kinaza aktywowana stresem (SAPK)

\section{Regulacja potranslacyjna}

Potranslacyjne mechanizmy regulacyjne GCL obejmują: formowanie holoenzymu i wzajemne interakcje podjednostek, fosforylację, hydrolizę GCLc przez kaspazę-3 oraz kontrolę oddziaływania podjednostek GCL przez układ NADPH/NADP+ [3]. Modyfikacje potranslacyjne (zwłaszcza GCLc) wydają się mieć jednak mniejszy wpływ na aktywność GCL niż regulacja na poziomie transkrypcji.

\section{Formowanie holoenzymu i wzajemne interakcje podjednostek}

Poziomy ekspresji dwóch podjednostek GCL są najważniejszymi wyznacznikami formowania holoenzymu i jego aktywności [3]. Dla większości tkanek GCLm uznaje się za podjednostkę ograniczającą, a wzrost ekspresji GCLm oraz stosunek 1:1 GCLc do GCLm za czynniki warunkujące maksymalną zdolność formowania się holoenzymu i nasilenia aktywności katalitycznej GCL [30]. Podjednostki GCL są ze sobą połączone głównie za pomocą wiązań 
dwusiarczkowych oraz wiązań niekowalencyjnych [3]. W warunkach redukujących dochodzi do zerwania mostków disiarczkowych i zmniejszenia aktywności GCL. Natomiast w warunkach utleniania, wraz z obniżeniem poziomu GSH, nasila się proces formowania holoenzymu [31]. Sugeruje się, że zmiany konformacyjne wywołane częściową dysocjacją podjednostek GLC powodują odsłonięcie miejsc wiążących glutaminian na GLCc i czynią ją bardziej dostępną dla GSH, umożliwiając tym samym hamowanie wsteczne [32].

Ludzki GCL zawiera 14 reszt cysteinowych na GCLc i 6 reszt cysteinowych na GCLm biorących udział w tworzeniu wiązań disiarczkowych holoenzymu [33]. Podstawową rolę w interakcji między podjednostkami przypisuje się reszcie Cys553 na GCLc [34]. Wykazano, że 4-HNE nie tylko reguluje GCL na poziomie transkrypcji, ale także potranslacyjnie przez bezpośrednią modyfikację reszt cysteinowych na obu podjednostkach, co wpływa na formowanie holoenzymu i aktywność GCL [35]. Modyfikacja przez 4-HNE Cys-553 na
GCLc i Cys-35 na GCLm nasila aktywność enzymatyczną GCLc. Zatem wzrost wydajności syntezy GSH zachodzący równocześnie ze wzrostem transkrypcji GCLc i GCLm może w warunkach stresu oksydacyjnego być skutecznym sposobem utrzymania komórkowej homeostazy GSH.

\section{Fosforylacja}

GCL jest negatywnie regulowany zarówno w procesie fosforylacji katalizowanej przez kinazy, jak i autofosforylacji [3]. Fosforylacja reszt serynowych i treoninowych podjednostki GCLc przez kinazę białkową A (PKA), PKC lub zależną od $\mathrm{Ca}^{2+}$ i kalmoduliny kinazę II (CaMKII) obniża aktywność enzymatyczną GCL [36]. Miejsca fosforylacji na GCLc sa prawdopodobnie identyczne dla tych trzech kinaz. Fosforylacja GCLc nie powoduje dysocjacji holoenzymu GCL. To sugeruje, iż ten rodzaj modyfikacji potranslacyjnej indukuje

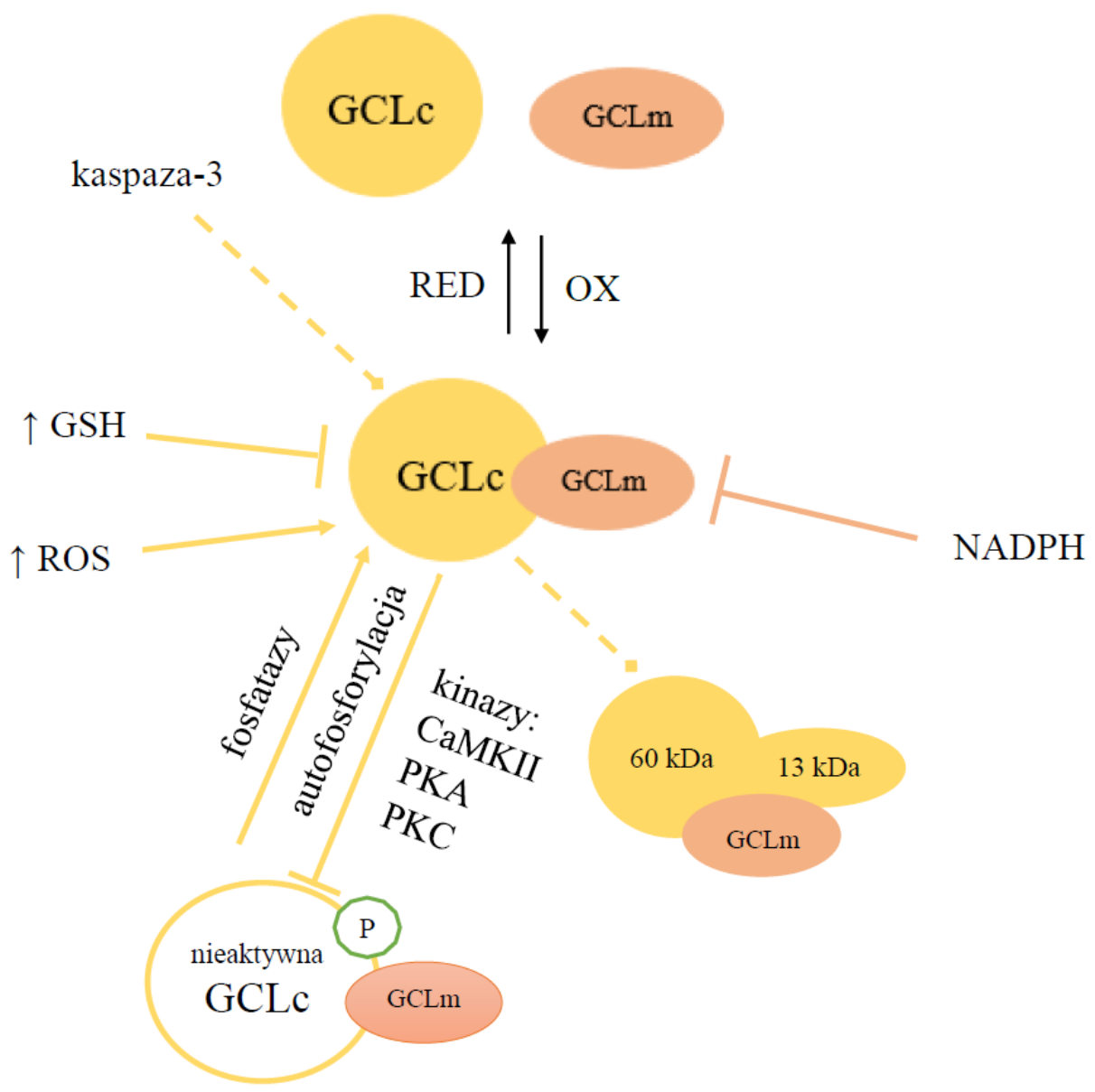

Rycina 3. Potranslacyjna regulacja aktywności ligazy Y-glutamylocysteiny;

RED - redukcja, OX - utlenianie, ROS - reaktywne formy tlenu, CaMKII - kinaza białkowa aktywowana przez Ca ${ }^{2+}$ i kalmodulinę, PKA kinaza białkowa A, PKC - kinaza białkowa C, NADPH - zredukowany fosforan dinukleotydu nikotynoamidoadeninowego 
zmiany konformacyjne hamujące aktywność enzymatyczną, ale pozostaje bez wpływu na tworzenie holoenzymu czy powinowactwo substratów. Natomiast powtórna aktywacja GCL jest związana z jej defosforylacją przez fosfatazy [37]. Przypuszcza się zatem, że GCL występuje in vivo jako mieszanina postaci ufosforylowanej i zdefosforylowanej, a zmiany stopnia fosforylacji to swoisty przełącznik między postacią aktywną a nieaktywną [4].

Istotne, że GCLc wykazuje także aktywność ATPazy, która umożliwia jej autofosforylację, zachodzącą najprawdopodobniej $w$ obrębie lub $w$ pobliżu miejsca aktywnego [38]. Tak jak w przypadku fosforylacji przez kinazy, proces autofosforylacji GCLc obniża aktywność enzymatyczną GCL. Natomiast podjednostka GCLm nie podlega regulacji ani przez fosforylację ani też autofosforylację [38].

\section{Hydroliza GCLc przez kaspazę-3}

Podczas apoptozy podjednostka GCLc $(73 \mathrm{kDa})$ może ulec rozszczepieniu w mechanizmie zależnym od kaspazy-3 na Ni C-końcowe fragmenty o masie odpowiednio 60 i $13 \mathrm{kDa}$ [1]. Miejsce hydrolizy GCLc (Asp499) przez kaspazę-3 znajduje się na N-końcu zawierającym Cys553 zaangażowaną w tworzenie mostka disiarczkowego z GCLm [34]. Zatem teoretycznie rozpad GCLc powinien spowodować albo obniżenie aktywności GCL, albo zaburzenie formowania holoenzymu. Jednak jak dotąd nie stwierdzono redukcji aktywności GCL podczas apoptotycznej śmierci komórki [39]. $Z$ badań in vitro wynika, że hydroliza GCLc przez kaspazę-3 nie powoduje oddysocjowania małego fragmentu (13 kDa) zawierającego miejsca wiązania GCLm od większej domeny (60 kDa). To prawdopodobnie sprawia, że GCLc zachowuje pełną aktywność enzymatyczną, a rozszczepienie GLCc przez kaspazę-3 nie wpływa na jej zdolność do oddziaływania z GCLm i formowanie w pełni funkcjonalnego holoenzymu GCL [1].

\section{Kontrola oddziaływania podjednostek GCL przez układ NADPH/NADP ${ }^{+}$}

Reakcja recyklingu glutationu polegająca na redukcji GSSG do GSH jest katalizowana przez GR i wymaga obecności zredukowanego fosforanu dinukleotydu nikotynoamidoadeninowego (NADPH) jako donora elektronów. Dostępność NADPH jest zatem czynnikiem ograniczającym efektywność enzymatyczną GR, który nie tylko wpływa na komórkowy stan oksydacyjno-redukcyjny, ale prawdopodobnie także na pobudzenie transkrypcji i potranslacyjne interakcje podjednostek GCL [3]. Potwierdzają to wyniki badania przeprowadzonego na Drosophila melanogaster, w którym wykazano, iż NADPH (niezależnie od udziału w recyklingu GSH) bezpośrednio nasila aktywność GCL [37]. Sekwencja ludzkiej GCLm jest podobna do sekwencji aldo-keto reduktaz, których aktywność enzymatyczna ściśle zależy od NADPH [1]. Na obecnym etapie wiedzy przyjmuje się, że podjednostka GCLm wykorzystująca jako kofaktor NADPH może być zaangażowana w uwalnianie fosforanu podczas pierwszej reakcji syntezy GSH [40].

\section{Schorzenia związane ze zmianami aktywności GCL}

W wielu chorobach pod wpływem czynników genetycznych lub środowiskowych obserwuje się obniżenie aktywności GCL i stężenia GSH do poziomów niewystarczających dla prawidłowej ochrony przed stresem oksydacyjnym [41, 42]. Natomiast wzrost ekspresji genu kodującego GCLc występuje w niektórych nowotworach i może być przyczyną niepowodzenia terapii onkologicznej.

\section{Niedobór ligazy y-glutamylocysteinylowej}

Niedobór ligazy y-glutamylocysteinylowej jest bardzo rzadką chorobą genetyczną $(<1 / 1000$ 000) dziedziczoną w sposób autosomalny recesywny, charakteryzującą się anemią hemolityczną, a w cięższych przypadkach zaburzeniami neurologicznymi [43]. Rozpoznanie ustala się na podstawie: niskiej aktywności GCL w erytrocytach, limfocytach i/lub hodowanych fibroblastach skóry, niskiego poziomu GSH i Y-GC w erytrocytach i/lub hodowanych fibroblastach skóry oraz występowania mutacji w genach kodujących GCL [43].

Pacjenci zdiagnozowani w kierunku wrodzonych niedoborów GCL posiadali mutacje homozygotyczne wyłącznie w genie GCLc. W obrębie tego genu potwierdzono obecność sześciu mutacji zmiany sensu, tj. c.379C>T (p.R127C), c.1109A >T (p.H370L), c.473C>T (p.P158L), c.1241C >T (p.P414L), c.1772G $>A(p . S 591 N)$ oraz c.514T $>A$ (p.S172T) [41, 43, 44, 45]. Ze względu na to, iż wszystkie zmiany są mutacjami missensownymi, to zostaje zachowana szczątkowa aktywność GCL. Mutacje typu nonsens, przesunięcia ramki odczytu czy delecja powodowałyby całkowitą utratą aktywności enzymu i mogłyby zagrażać życiu. Jak dotąd nie opisano żadnej mutacji w obrębie genu kodującego GCLm, która miałaby związek z rozwojem tej rzadkiej choroby.

Wszyscy opisani pacjenci $z$ niedobrem GCL mieli anemię hemolityczną, zwykle łagodną [45]. W kilku przypadkach choroba miała jednak ciężki przebieg, a fenotyp charakteryzował się występowaniem w dzieciństwie dodatkowych objawów neurologicznych pod postacią ataksji rdzeniowo-móżdżkowej, neuropatii obwodowej, miopatii, 
dysleksji, dysartii, opóźnienia rozwoju psychoruchowego [41, 43]. Obserwowano także aminoacydurię, przemijającą żółtaczkę, retikulocytozę i hepatosplenomegalię [45]. Ponieważ niedobór GCL może mieć fenotyp łagodny (nieneurologiczny) lub cięższy fenotyp $z$ objawami neurologicznymi, to sprawia, że obraz kliniczny jest podobny do niedoboru syntetazy glutationu z 5-oksoprolinurią. Stąd też uważa się, iż część przypadków niedoboru GCL może pozostawać niezdiagnozowana lub zdiagnozowana błędnie [41].

\section{Choroby neurodegeneracyjne}

Nasilający się z wiekiem stres oksydacyjny z jednoczesnym osłabieniem mechanizmów obrony antyoksydacyjnej przyczyniają się do uszkodzenia i zaniku neuronów mózgu, czyli zmian typowych dla procesu neurodegeneracyjnego. Stopniowe obniżanie $w$ trakcie starzenia poziomu GSH i aktywności enzymów GSH-zależnych jest uważane za czynnik odpowiedzialny za powstawanie i progresję chorób neurodegeneracyjnych wieku podeszłego, takich jak choroba Parkinsona (Parkinson disease, PD) czy choroba Alzheimera (Alzheimer disease, AD) [46, 47]. W kilku badaniach prowadzonych zarówno in vitro, jak $\mathrm{i}$ in vivo podjęto próby wyjaśnienia mechanizmów łączących zmiany aktywności GCL z patogenezą tych schorzeń.

Badania pośmiertne mózgów chorych na PD wskazują na wyczerpanie rezerw GSH jako przyczynę neurodegeneracji. Wykazano w nich, że poziom całkowitego glutationu w istocie czarnej obniża się o $40-50 \%$ i jest swoisty dla neuronów dopaminergicznych [48]. U podstaw tego zjawiska może leżeć osłabienie aktywności enzymatycznej GCL i zaburzenia syntezy GSH. Z użyciem interferencji RNA (RNA interference, RNAi), naturalnego mechanizmu wyciszania ekspresji genów za pomocą krótkiego interferującego RNA (short interfering RNA, siRNA), stwierdzono bowiem, że brak ekspresji GCL powoduje postępującą degenerację neuronów dopaminergicznych istoty czarnej [49]. Również inhibicja GCL przez L-butionino-S,R-sulfoksyminę (L-buthioninesulfoximine, BSO) powodująca wyczerpanie GSH nasila apoptozę komórek dopaminergicznych SH-SY5Y idukowaną przez lewoskrętną dopaminę (L-DOPA) [50].

Podjednostka Gclc odgrywa podstawową rolę w utrzymaniu nie tylko wewnątrzkomórkowej, ale także mitochondrialnej homeostazy GSH. Jest to szczególnie istotne ze względu na to, że dysfunkcje mitochondriów mogą być przyczyną chorób neurodegeneracyjnych. Feng i wsp. [51] zbadali u myszy przebieg procesu neurodegeneracyjnego wywołanego w różnych stadiach rozwoju i strukturach mózgu deficytem GLCc z użyciem systemu indukowalnej/warunkowej ekspresji genów (system Cre/loxP). Stwierdzono, że myszy z nokautem genu $G L C c$, niezależnie od fazy rozwoju i regionu mózgu, którego dotyczył, wykazywały dysfunkcję mitochondriów, spadek mitochondrialnej zawartości GSH i zmianę stosunku GSH/GSSG. Na postępującą neurodegenerację wskazywały takie objawy jak atrofia mózgu, astroglioza oraz uszkodzenie neuronów (zwłaszcza w obszarze hipokampa), które przekładały się na zaburzenia poznawcze i ruchowe tych zwierząt [51]. Fernandez-Fernandez i wsp. [52] u myszy z delecją genu GCLC również obserwowali stopniowe obniżanie poziomu GSH w regionie CA1 hipokampa prowadzące do uszkodzenia dendrytów i zaburzeń pamięci.

Związany z wiekiem niski poziom GSH w mózgu może wynikać nie tylko z zaburzeń ekspresji podjednostki GCLc, ale także $z$ down-regulacji GCLm, a w konsekwencji zmiany stosunku GCLc:GCLm i obniżenia aktywności GCL. Świadczą o tym rezultaty eksperymentu, w którym u starzejących się szczurów stwierdzono stopniowe obniżanie ekspresji genu kodującego GCLm w móżdżku, korze mózgu i hipokampie. Zjawisku temu towarzyszyło zmniejszenie aktywności GCL i stężenia $\mathrm{GSH}$, bez istotnych zmian w zawartości GSSG oraz aktywności GS, Y-glutamylotranspeptydazy (y-glutamyltranspeptidase, $y-G T)$ i GR w tych strukturach [53]. Należy podkreślić, iż jak dotąd jest to jedyna publikacja koncentrująca się na zmianach ekspresji GCLm w mózgu podczas procesu starzenia się. Jednak przytoczone wyżej dane sugerują, że postępujący z wiekiem spadek mózgowego GSH może być skutkiem wyhamowania pierwszej reakcji jego syntezy katalizowanej przez GCL.

\section{Choroby wątroby}

Zmniejszanie zasobów GSH jest główną przyczyną degeneracji i obumierania hepatocytów, zaburzenia metabolizmu lipidów (steatozy) oraz rozwoju stanu zapalnego i zwłóknienia/marskości wątroby. Takie zmiany patologiczne występują w schorzeniach hepatologicznych o różnej etiologii, tj. np. niealkoholowej stłuszczeniowej chorobie wątroby (nonalcoholic fatty liver disease, NAFLD) czy też polekowym uszkodzeniu wątroby (drug-induced liver injury, DILI) [54].

W wątrobie około $10 \%$ całkowitego GSH jest aktywnie transportowane do mitochondriów, gdzie osiąga stężenia porównywalne do cytozolowych, czyli 5-10 mM [55]. Zatem GSH odgrywa główną rolę w funkcjonowaniu tych organelli, intensywnie zużywających tlen i generujących RONS.

$\mathrm{U}$ myszy z delecją genu kodującego podjednostkę GCLc w hepatocytach stwierdzono postępującą deplecję GSH. W 28. dniu życia postnatalnego zwierząt poziom całkowitego wątrobowego GSH zmniejszył się aż o $95 \%$ w porównaniu do kontroli. Wątroby myszy z nokutem Gclc cechował postępujący proces stłuszczenia i nekrozapalenia prowadzący do zgonu zwierząt w 30. dniu życia postnatalnego z powodu 
niewydolności tego organu [55, 56]. Badania ultrastrukturalne wykazały obrzmienie i dysfunkcję mitochondriów, którym towarzyszył dramatyczny spadek mitochondrialnego $\mathrm{GSH}$ oraz wytwarzania ATP [56]. To potwierdza, że mitochondria są organellami komórkowymi najbardziej wrażliwymi na niedobór GSH, a zaburzenie mitochondrialnej homeostazy GSH determinuje ciężkość i przebieg NAFLD [55].

Przeprowadzono także badania na myszach z nokautem genu GCLm w celu określenia roli GSH w patogenezie DILI [57]. U części chorych przyczyną DILI jest zatrucie paracetamolem z powodu nieświadomego przedawkowania tego leku lub próby samobójczej. W dawkach terapeutycznych paracetamol ulega szybkiej detoksykacji przez koniugację jego reaktywnego metabolitu - $\mathrm{N}$-acetylo-p-benzochinonoiminy (NPQI) z GSH. Jednak dawki toksyczne powodują ostrą niewydolność wątroby o wieloczynnikowym mechanizmie obejmującym m.in. szybkie wyczerpanie komórkowej puli GSH, nasilenie wytwarzania RONS, aktywację proapoptotycznych szlaków sygnałowych związanych z kinazą JNK oraz S-nitrozylację białek mitochondrialnych [41, 58]. Ścisły związek hepatotoksyczności paracetamolu z deplecją GSH potwierdzają wyniki badania, w którym obserwowano po podaniu paracetamolu (500 mg i.p.) znacznie cięższe uszkodzenie wątroby u myszy z delecją GCLm w porównaniu do szczepu dzikiego [58].

\section{Choroby nowotworowe}

Procesowi kancerogenezy zawsze towarzyszy zaburzenie komórkowej równowagi oksydacyjno-redukcyjnej. Ponieważ nasilone wytwarzanie RONS jest toksyczne dla komórek nowotworowych, dlatego wytworzyły one mechanizmy adaptacyjne polegające na zwiększonej ekspresji genów kodujących białka antyoksydacyjne. Komórki rakowe wykazują więc wysoki potencjał antyoksydacyjny i mogą być niewrażliwe na działanie endo- i egzogennych utleniaczy [59].

W wielu typach nowotworów litych obserwuje się wyraźny wzrost ekspresji GCLc i nasilenie syntezy GSH w porównaniu do zdrowej tkanki, co może się przyczyniać do progresji choroby oraz oporności na radio- $i$ chemioterapię $[39,60$, 61]. Zwiększona podaż GSH przyspiesza bowiem proliferację komórek rakowych i hamuje apoptozę [62]. Rola jaką odgrywa GSH w procesie namnażania komórek polega na redukcji glutaredoksyny lub tioredoksyny, a to wpływa na aktywność reduktazy rybonukleotydowej, czyli enzymu warunkującego szybkość syntezy DNA [62]. Natomiast występowanie pozytywnej korelacji między poziomem ekspresji onkogenu Bcl-2 a stężeniem GSH w komórkach nowotworowych determinuje ich oporność na apoptozę [63, 64].

Nadekspresję podjednostki GCLc stwierdzono m.in. w międzybłoniaku, raku okrężnicy, raku nerkowokomórkowym oraz przerzutach do wątroby $w$ przebiegu raka jelita grubego [65, 66, 67]. Także u pacjentów z rakiem wątrobowokomórkowym po zabiegu resekcyjnym aktywność transkrypcyjna genu GCLC w tkankach guza była znacznie większa niż w tkankach go otaczających i pozytywnie korelowała ze stopniem zróżnicowania histologicznego, inwazją naczyń krwionośnych i stadium choroby [68]. Niedawne badania odnotowują również zależność między ekspresją genu GLCc w tkance nowotworowej a opornością na leki przeciwnowotworowe. Stwierdzono, że wysoka ekspresja mRNA dla GCLc jest związana z opornością raka piersi na tamoksyfen oraz nowotworów płuc, głowy i szyi na cisplatynę [69, 70, 71, 72]. Niektóre komórki nowotworowe, oprócz większej aktywności GCL, wykazują jednocześnie także wyższą ekspresję białek oporności wielolekowej (multidrug resistance protein 1, MRP). Wiadomo, że prawie wszystkie białka rodziny MRP transportują koniugaty cytostatyków z GSH i/lub GSH, a to przyczynia się do chemiooporności [60]. Wszystkie te dane sugerują, że GCLC może działać jak onkogen, a określenie poziomu jego ekspresji może mieć znaczenie predykcyjne prognozujące możliwość wystąpienia oporności na leki cytostatyczne [73].

\section{Implikacje terapeutyczne}

Przyczyną wielu przewlekłych schorzeń wywołanych przez czynniki genetyczne lub środowiskowe jest wyczerpanie zasobów GSH, którego objawem jest zwiększona wrażliwość na stres oksydacyjny [74]. Powszechnie uważa się, że leki lub suplementy zdolne do podnoszenia poziomu GSH mogą wykazywać w nich potencjał leczniczy. Dotychczasowe strategie terapeutyczne skupiały się głównie na uzupełnianiu niedoborów GSH przez podawanie egzogennego GSH i jego estrów lub prekursorów cysteiny, takich jak metionina, $\mathrm{N}$-acetylocysteina (NAC) czy kwas 2-oksotiazolidyno-4karboksylowy (OTC) [75, 76]. Niestety, egzogenne podawanie GSH jest nieskuteczne, gdyż nie może on penetrować błony komórkowe. Ponadto wykazano, że u ludzi GSH jest szybko eliminowany z osocza i ma bardzo krótki czas półtrwania wynoszący około 1,6 min [77].

Suplementacja lipofilowymi monoestrami GSH (metylowym, etylowym, propylowym) wiąże się z ryzykiem cytotoksycznego działania odpowiedniego alkoholu uwolnionego na skutek ich enzymatycznej hydrolizy [78]. Cysteina, czyli aminokwas stymulujący syntezę GSH de novo, nie może być stosowana jako lek, ponieważ jest silną neurotoksyną. Prekursory cysteiny, metionina i OTC, są znacznie bezpieczniejsze, ale ich przemiany enzymatyczne wymagają nakładów energii w postaci ATP, których dotknięte stresem oksydacyjnym komórki nie mogą pokryć [2]. NAC także nie jest skuteczna w przewlekłych stanach 
niedoboru GSH, mimo iż stanowi cenne antidotum w zatruciu paracetamolem ze względu na neutralizację NAPQI [79]. W schorzeniach chronicznych jedną z przyczyn progresywnego zaburzenia homeostazy GSH wydaje się niedobór lub osłabienie aktywności enzymatycznej GCL [8]. To wszystko sprawia, że y-GC przez ominięcie GCL może być skutecznym klinicznie środkiem zwiększającym poziom GSH.

Natomiast przeciwna strategia, oparta na zahamowaniu GCL i deplecji GSH wraz z jednoczesnym podawaniem cytostatyków, mogłaby być szansą na poprawę skuteczności chemioterapii chorób nowotworowych. Od wielu lat znane są specyficzne inhibitory GCL, takie jak propioninosulfoksymina czy BSO, których zastosowanie mogłoby zmniejszyć stężenie GSH w komórkach rakowych. Jednak ich podstawową wadą jest brak specyficzności wobec komórek zmienionych nowotworowo i toksyczny wpływ na zdrowe tkanki [62]. Zastosowanie zatem takiej terapii nie jest możliwe, gdyż GSH nie mógłby pełnić roli ochronnej przed szkodliwym wpływem ksenobiotyków i działaniami niepożądanymi innych metod leczenia nowotworów.

\section{Potencjał leczniczy y-GC}

Wiele danych potwierdza możliwość użycia w terapii uzupełniającej chorób przebiegających z deficytem GSH egzogennej Y-GC jako bezpośredniego prekursora GSH. Co istotne, Y-GC wykazuje własną aktywność antyoksydacyjną związaną z obecnością grupy tiolowej reszty cysteinowej. Ponadto zarówno w warunkach in vitro, jak i in vivo wykazano, że $\mathrm{Y}$-GC może bezpośrednio zastąpić GSH działając jako kofaktor GPx [80].

Ze względu na niskie cytozolowe stężenie $\mathrm{Y}$-GC wynoszące około $7 \mu \mathrm{M}$, jest ona przenoszona biernie lub aktywnie przez błonowy transporter dipeptydów do wnętrza komórki, gdzie skutecznie omija dysfunkcyjną GCL [8]. Można więc oczekiwać, że przy odpowiednim dostępie ATP i glicyny cała pula $\mathrm{y}-\mathrm{GC}$ wychwycona przez komórkę zostanie przekształcona do GSH z udziałem GS. Natomiast przyrost stężenia GSH będzie uwarunkowany szybkością wychwytu Y-GC i zużywania GSH [3].

Niewątpliwą zaletą Y-GC jest możliwość podawania drogą doustną ze względu na absorpcję w jelicie cienkim. To odróżnia ją od innych dipeptydów, które nie są szczególnie przydatne jako leki doustne, ponieważ łatwo ulegają hydrolizie we krwi lub w przewodzie pokarmowym. Jednak ze względu na obecność wspomnianego już wiązania izopeptydowego, y-GC jest oporna na działanie większości proteaz i aminoproteaz [8]. Wchłonięta z jelit $\mathrm{Y}-\mathrm{GC}$ jest skutecznie wychwytywana przez wątrobę. Tam ulega konwersji do GSH i następnie jest transportowana, prawdopodobnie jako związek pośredni, czyli y-glutamylocystyna (Y-Glu-[Cys]2) do innych narządów, takich jak nerki, serce i mózg [3]. Alternatywnie, y-GC może być bezpośrednio wchłaniana do krwiobiegu, co powoduje jej szybką dystrybucję systemową [3].

W badaniach toksyczności ostrej i przewlekłej Y-GC przeprowadzonych na szczurach nie stwierdzono śmiertelności i jakichkolwiek objawów niepożądanych po podaniu doustnym odpowiednio pojedynczej dawki $2000 \mathrm{mg} /$ $\mathrm{kg}$ lub dawki $1000 \mathrm{mg} / \mathrm{kg}$ przez 90 dni [81]. Dane te stanowiły podstawę do dalszej oceny efektywności i bezpieczeństwa y-GC u ludzi. W 2017 r. opublikowano wyniki pierwszej próby klinicznej przeprowadzonej na zdrowych ochotnikach, w której dokonano pomiaru poziomu GSH w limfocytach po pojedycznym doustnym podaniu $2 \mathrm{~g}$ lub $4 \mathrm{~g}$ Y-GC [8]. Zmiany stężenia GSH w limfocytach wybrano jako surogat pomiaru komórkowego wychwytu $\mathrm{Y}-\mathrm{GC}$, a tym samym biodostępności. W ciągu 3 godzin od zażycia stwierdzono 2-krotny i 3-krotny wzrost stężenia GSH w limfocytach, odpowiednio dla dawki 2 i $4 \mathrm{~g}$, potwierdzając tym samym potencjalną użyteczność kliniczną Y-GC. Również w wielu wcześniejszych pracach doświadczalnych in vivo wykazano, że podanie $\mathrm{y}$-GC lub jej estru etylowego wyraźnie zwiększa wewnątrzkomórkowy poziom GSH w tkance nerwowej, wątrobie i sercu, chroniąc je tym samym przed uszkodzeniem oksydacyjnym [36, 82, 83].

Opublikowane niedawno wyniki kilku eksperymentów prowadzonych $\mathrm{w}$ warunkach in vitro i in vivo ujawniają silne właściwości przeciwzapalne $\mathrm{Y}-\mathrm{GC}$ i sugerują możliwość jej wykorzystania w terapii chorób o podłożu zapalnym. Stwierdzono bowiem, że $y-G C$ znacznie osłabia ogólnoustrojową reakcję zapalną i redukuje śmiertelność myszy z sepsą. Natomiast $w$ badaniu in vitro podanie $\mathrm{y}-\mathrm{GC}$ do hodowli mysich makrofagów RAW264.7 hamowało stymulowane lipopolisacharydem (lipopolysaccharide, LPS) wydzielanie mediatorów reakcji zapalenia, tj. TNF- $\alpha, \mathrm{IL}-1 \beta$, NO, Cox-2 i białka o dużej ruchliwości elektroforetycznej (HMGB-1) [84]. Badania mechanistyczne wykazały, że stymulacja LPS powoduje aktywację czynników transkrypcyjnych Nrf2 i NF-kB z następczym wzrostem GS i nasileniem syntezy GSH z y-GC. Ponadto, zarówno in vitro, jak i in vivo, efekt przeciwzapalny $\mathrm{Y}$-GC był znacznie lepszy w porównaniu do NAC czy GSH [84]. Zdolność Y-GC do hamowania wydzielania cytokin prozapalnych stwierdzono także w hodowli komórkowej ludzkich astrocytów traktowanej rozpuszczalnymi oligomerami $\beta$-amyloidu, w mysim modelu zapalenia jelita grubego oraz szczurzych modelach nefrotoksyczności indukowanej ołowiem i hepatotoksyczności wywołanej kadmem [19, 42, 85, 86].

\section{Podsumowanie}

GCL jest enzymem warunkującym szybkość syntezy i wewnątrzkomórkowe stężenie GSH, którego mechanizmy 
regulacji ekspresji i aktywności są złożone i wieloczynnikowe. Ich dokładne poznanie jest istotne do opracowania strategii terapeutycznych zorientowanych na możliwości modulacji syntezy GSH. Tym bardziej że w ostatnich latach znacznie wzrosło zainteresowanie udziałem GCL w patogenezie chorób związanych z wiekiem, a zwłaszcza neurodegeneracji, schorzeń wątroby i nowotworów. Wyniki badań przedklinicznych wskazują na terapeutyczny potencjał Y-GC w leczeniu uzupełniającym chorób przebiegających z przewleką deplecją GSH spowodowaną niedoborem genetycznym lub dysfunkcją GCL.

\section{Wykaz skrótów}

AD - choroba Alzheimera; ADP - adenozynodifosforan; AP-1 - białko aktywatorowe-1; ARE - element odpowiedzi antyoksydacyjnej; ATP - adenozynotrifosforan; BHA - butylowany hydroksyanizol; BSO - L-butionino-S,Rsulfoksymina; CaMKII - kinaza białkowa aktywowana przez $\mathrm{Ca}^{2+} \mathrm{i}$ kalmodulinę; CREB - czynnik transkrypcyjny aktywowany w odpowiedzi na cAMP; DILI - polekowe uszkodzenie wątroby; ERK - kinaza regulowana przez sygnały zewnątrzkomórkowe; $\mathbf{Y - G C ~ - ~ \gamma - g l u t a m y l o c y s t e i n a ; ~}$ GCL - ligaza Y-glutamylocysteiny; GCLc - podjednostka katalityczna ligazy y-glutamylocysteiny; GCLm podjednostka modulatorowa ligazy $Y$-glutamylocysteiny; GPX - peroksydaza glutationowa; GS - syntetaza glutationowa; GSH - glutation zredukowany; GSSG glutation utleniony; GST - S-transferaza glutationowa; Y-GT - y-glutamylotranspeptydaza; 4-HNE - 4-hydroksynonenal; JNK - kinaza domeny N-końcowej białka Jun (inaczej: kinazy aktywowane stresem, SAPK); Keap-1 - inhibitor Nrf2; L-DOPA - dopamina lewoskrętna; LPS - lipopolisacharyd; Maf - białko włókniakomięsaka mięśniowo-szkieletowego; MRE - element odpowiedzi na metale; MRP - białka oporności wielolekowej; NAC - N-acetylocysteina; NADP - fosforan dinukleotydu nikotynoamidoadeninowego; NADPH - zredukowany fosforan dinukleotydu nikotynoamidoadeninowego; NAFLD - niealkoholowa stłuszczeniowa choroba wątroby; Nrf2 - jądrowy czynnik transkrypcyjny 2; OTC - kwas 2-oksotiazolidyno-4-karboksylowy; PD - choroba Parkinsona; PI3K - kinaza-3- fosfatydyloinozytolu; PI3K/Akt - ścieżka sygnałowa kinazy 3-fosfatydyloinozytolu i kinazy białkowej AKT; PKC - kinaza białkowa C; RNAi - interferencja RNA; RONS - reaktywne formy tlenu i azotu; si-RNA - krótkie interferujące RNA; SP-1 - białko wiążące-1; TBH - tertbutylohydrochinon.

\section{Finansowanie}

Praca powstała dzięki wsparciu finansowemu Narodowego Centrum Nauki; nr projektu badawczego 2019/35/N/ NZ7/03071.

\section{Konflikt interesów}

Autorki deklarują brak potencjalnych konfliktów interesów.

\section{Piśmiennictwo}

[1] Franklin C.C., Backos D.S., Mohar I., White C.C., Forman H.J., Kavanagh T.J.: Structure, function, and post-translational regulation of the catalytic and modifier subunits of glutamate cysteine ligase. Mol. Aspects Med., 2009; 30: 86-98

[2] Bilska A., Kryczyk A., Włodek L.: The different aspects of the biological role of glutathione. Postępy Hig. Med. Dośw., 2007; 61: 438-453

[3] Ferguson G., Bridge W.: Glutamate cysteine ligase and the age-related decline in cellular glutathione: The therapeutic potential of Y-glutamylcysteine. Arch. Biochem. Biophys., 2016; 593: 12-23

[4] Lu S.C.: Glutathione synthesis. Biochim. Biophys. Acta, 2013; 1830: 3143-3153

[5] Li S., Li X., Rozanski G.J.: Regulation of glutathione in cardiac myocytes. J. Mol. Cell. Cardiol., 2003; 35: 1145-1152

[6] Pompella A., Corti A., Paolicchi A., Giommarelli C., Zunino F.: Y-glutamyltransferase, redox regulation and cancer drug resistance. Curr. Opin. Pharmacol., 2007; 7: 360-366

[7] Meister A.: On the discovery of glutathione. Trends. Biochem. Sci., 1988; 13: 185-188

[8] Zarka M.H., Bridge W.J.: Oral administration of y-glutamylcysteine increases intracellular glutathione levels above homeostasis in a randomised human trial pilot study. Redox Biol., 2017; 11: 631-636

[9] Franco R., Schoneveld O.J., Pappa A., Panayiotidis M.I.: The central role of glutathione in the pathophysiology of human diseases. Arch. Physiol. Biochem., 2007; 113: 234-258

[10] Forman H.J., Zhang H., Rinna A.: Glutathione: Overview of its protective roles, measurement, and biosynthesis. Mol. Aspects Med., 2009; 30: 1-12

[11] Yang Y., Chen Y., Johansson E., Schneider S.N., Shertzer H.G., Nebert D.W., Dalton T.P.: Interaction between the catalytic and modifier subunits of glutamate-cysteine ligase. Biochem. Pharmacol., 2007; 74: 372-381

[12] Shi Z.Z., Osei-Frimpong J., Kala G., Kala S.V., Barrios R.J., Habib G.M., Lukin D.J., Danney C.M., Matzuk M.M., Lieberman M.W.: Glutathione synthesis is essential for mouse development but not for cell growth in culture. Proc. Natl. Acad. Sci. USA, 2000; 97: 5101-5106 
[13] Yang Y., Dieter M.Z., Chen Y., Shertzer H.G., Nebert D.W., Dalton T.P.: Initial characterization of the glutamate-cysteine ligase modifier subunit Gclm(-/-) knockout mouse. Novel model system for a severely compromised oxidative stress response. J. Biol. Chem., 2002; 277: 49446-49452

[14] Mulcahy R.T., Bailey H.H., Gipp J.J.: Up-regulation of $\mathrm{Y}$-glutamylcysteine synthetase activity in melphalan-resistant human multiple myeloma cells expressing increased glutathione levels. Cancer Chemother. Pharmacol., 1994; 34: 67-71

[15] Iles K.E., Liu R.M.: Mechanisms of glutamate cysteine ligase (GCL) induction by 4-hydroxynonenal. Free Radic. Biol. Med., 2005; 38: 547-556

[16] Krejsa C.M., Franklin C.C., White C.C., Ledbetter J.A., Schieven G.L., Kavanagh T.J.: Rapid activation of glutamate cysteine ligase following oxidative stress. J. Biol. Chem., 2010; 285: 16116-16124

[17] Liu R.M., Gao L., Choi J., Forman H.J.: Gamma-glutamylcysteine synthetase: mRNA stabilization and independent subunit transcription by 4-hydroxy-2-nonenal. Am. J. Physiol., 1998; 275: L861-L869

[18] Liu R.M., Hu H., Robison T.W., Forman H.J.: Differential enhancement of $\mathrm{\gamma}$-glutamyl transpeptidase and $\mathrm{\gamma}$-glutamylcysteine synthetase by tert-butylhydroquinone in rat lung epithelial L2 cells. Am. J. Respir. Cell Mol. Biol., 1996; 14: 186-191

[19] Zhang H., Court N., Forman H.J.: Submicromolar concentrations of 4-hydroxynonenal induce glutamate cysteine ligase expression in HBE1 cells. Redox Rep., 2007; 12: 101-106

[20] Benassi B., Fanciulli M., Fiorentino F., Porrello A., Chiorino G., Loda M., Zupi G., Biroccio A.: c-Myc phosphorylation is required for cellular response to oxidative stress. Mol. Cell., 2006; 21: 509519

[21] Cai J., Huang Z.Z., Lu S.C.: Differential regulation of Y-glutamylcysteine synthetase heavy and light subunit gene expression. Biochem. J., 1997; 326: 167-172

[22] Lu S.C., Kuhlenkamp J., Garcia-Ruiz C., Kaplowitz N.: Hormone-mediated down-regulation of hepatic glutathione synthesis in the rat. J. Clin. Invest., 1991; 88: 260-269

[23] Kim S.K., Woodcroft K.J., Khodadadeh S.S., Novak R.F.: Insulin signaling regulates $\gamma$-glutamylcysteine ligase catalytic subunit expression in primary cultured rat hepatocytes. J. Pharmacol. Exp. Ther., 2004; 311: 99-108

[24] Eaton D.L., Hamel D.M.: Increase in Y-glutamylcysteine synthetase activity as a mechanism for butylated hydroxyanisole-mediated elevation of hepatic glutathione. Toxicol. Appl. Pharmacol., 1994; 126: 145-149

[25] Urata Y., Honma S., Goto S., Todoroki S., lida T., Cho S., Honma K., Kondo T.: Melatonin induces $\mathrm{Y}$-glutamylcysteine synthetase mediated by activator protein-1 in human vascular endothelial cells. Free Radic. Biol. Med., 1999; 27: 838-847

[26] Langston J.W., Li W., Harrison L., Aw T.Y.: Activation of promoter activity of the catalytic subunit of $Y$-glutamylcysteine ligase (GCL) in brain endothelial cells by insulin requires antioxidant response element 4 and altered glycemic status: Implication for GCL ex- pression and GSH synthesis. Free Radic. Biol. Med., 2011; 51: 1749-1757

[27] Kensler T.W., Wakabayashi N., Biswal S.: Cell survival responses to environmental stresses via the Keap1-Nrf2-ARE pathway. Annu. Rev. Pharmacol. Toxicol., 2007; 47: 89-116

[28] Chan K., Han X.D., Kan Y.W.: An important function of Nrf2 in combating oxidative stress: Detoxification of acetaminophen. Proc. Natl. Acad. Sci. USA, 2001; 98: 4611-4616

[29] Wild A.C., Moinova H.R., Mulcahy R.T.: Regulation of y-glutamylcysteine synthetase subunit gene expression by the transcription factor Nrf2. J. Biol. Chem., 1999; 274: 33627-33636

[30] Chen Y., Shertzer H.G., Schneider S.N., Nebert D.W., Dalton T.P.: Glutamate cysteine ligase catalysis: Dependence on ATP and modifier subunit for regulation of tissue glutathione levels. J. Biol. Chem., 2005; 280: 33766-33774

[31] Fraser J.A., Kansagra P., Kotecki C., Saunders R.D., McLellan L.I.: The modifier subunit of Drosophila glutamate-cysteine ligase regulates catalytic activity by covalent and noncovalent interactions and influences glutathione homeostasis in vivo. J. Biol. Chem., 2003; 278: 46369-46377

[32] Huang C.S., Chang L.S., Anderson M.E., Meister A.: Catalytic and regulatory properties of the heavy subunit of rat kidney gamma-glutamylcysteine synthetase. J. Biol. Chem., 1993; 268: 19675-19680

[33] Levonen A.L., Landar A., Ramachandran A., Ceaser E.K., Dickinson D.A., Zanoni G., Morrow J.D., Darley-Usmar V.M.: Cellular mechanisms of redox cell signalling: Role of cysteine modification in controlling antioxidant defences in response to electrophilic lipid oxidation products. Biochem. J., 2004; 378: 373-382

[34] Tu Z., Anders M.W.: Identification of an important cysteine residue in human glutamate-cysteine ligase catalytic subunit by sitedirected mutagenesis. Biochem. J., 1998; 336: 675-680

[35] Backos D.S., Fritz K.S., Roede J.R., Petersen D.R., Franklin C.C.: Posttranslational modification and regulation of glutamatecysteine ligase by the $\alpha, \beta$-unsaturated aldehyde 4-hydroxy-2-nonenal. Free Radic. Biol. Med., 2011; 50: 14-26

[36] Hayashi H., limuro M., Matsumoto Y., Kaneko M.: Effects of gamma-glutamylcysteine ethyl ester on heart mitochondrial creatine kinase activity: Involvement of sulfhydryl groups. Eur. J. Pharmacol., 1998; 349: 133-136

[37] Toroser D., Yarian C.S., Orr W.C., Sohal R.S.: Mechanisms of Y-glutamylcysteine ligase regulation. Biochim. Biophys. Acta, 2006; 1760: 233-244

[38] Sekhar K.R., Freeman M.L.: Autophosphorylation inhibits the activity of Y-glutamylcysteine synthetase. J. Enzyme Inhib., 1999; 14: 323-330

[39] Zhu M., Bowden G.T.: Molecular mechanism(s) for UV-B irradiation-induced glutathione depletion in cultured human keratinocytes. Photochem. Photobiol., 2004; 80: 191-196

[40] Soltaninassab S.R., Sekhar K.R., Meredith M.J., Freeman M.L.: Multi-faceted regulation of Y-glutamylcysteine synthetase. J. Cell Physiol., 2000; 182: 163-170 
[41] Abdelmegeed M.A., Jang S., Banerjee A., Hardwick J.P., Song B.J.: Robust protein nitration contributes to acetaminophen-induced mitochondrial dysfunction and acute liver injury. Free Radic. Biol. Med., 2013; 60: 211-222

[42] Braidy N., Zarka M., Jugder B.E., Welch J., Jayasena T., Chan D.K.Y., Sachdev P., Bridge W.: The precursor to glutathione (GSH), y-Glutamylcysteine (GGC), can ameliorate oxidative damage and neuroinflammation induced by $A \beta_{40}$ oligomers in human astrocytes. Front Aging Neurosci., 2019; 11: 177

[43] Ristoff E., Larsson A.: Inborn errors in the metabolism of glutathione. Orphanet J. Rare Dis., 2007; 2: 16

[44] Hamilton D., Wu J.H., Alaoui-Jamali M., Batist G.: A novel missense mutation in the $\mathrm{y}$-glutamylcysteine synthetase catalytic subunit gene causes both decreased enzymatic activity and glutathione production. Blood, 2003; 102: 725-730

[45] Mañú Pereira M., Gelbart T., Ristoff E., Crain K.C., Bergua J.M., López Lafuente A., Kalko S.G., García Mateos E., Beutler E., Vives Corrons J.L.: Chronic non-spherocytic hemolytic anemia associated with severe neurological disease due to $\gamma$-glutamylcysteine synthetase deficiency in a patient of Moroccan origin. Haematologica, 2007; 92: e102-105

[46] Gutowicz M.: The influence of reactive oxygen species on the central nervous system. Postępy Hig. Med. Dośw., 2011; 65: 104113

[47] Johnson W.M., Wilson-Delfosse A.L., Mieyal J.J.: Dysregulation of glutathione homeostasis in neurodegenerative diseases. Nutrients, 2012; 4: 1399-1440

[48] Pearce R.K., Owen A., Daniel S., Jenner P., Marsden C.D.: Alterations in the distribution of glutathione in the substantia nigra in Parkinson's disease. J. Neural. Transm., 1997; 104: 661-677

[49] Garrido M., Tereshchenko Y., Zhevtsova Z., Taschenberger G., Bähr M., Kügler S.: Glutathione depletion and overproduction both initiate degeneration of nigral dopaminergic neurons. Acta Neuropathol., 2011; 121: 475-485

[50] Sabens E.A., Distler A.M., Mieyal J.J.: Levodopa deactivates enzymes that regulate thiol-disulfide homeostasis and promotes neuronal cell death: Implications for therapy of Parkinson's disease. Biochemistry, 2010; 49: 2715-2724

[51] Feng W., Rosca M., Fan Y., Hu Y., Feng P., Lee H.G., Monnier V.M., Fan X.: Gclc deficiency in mouse CNS causes mitochondrial damage and neurodegeneration. Hum. Mol. Genet., 2017; 26: 1376-1390

[52] Fernandez-Fernandez S., Bobo-Jimenez V., Requejo-Aguilar R., Gonzalez-Fernandez S., Resch M., Carabias-Carrasco M., Ros J., Almeida A., Bolaños J.P.: Hippocampal neurons require a large pool of glutathione to sustain dendrite integrity and cognitive function. Redox Biol., 2018; 19: 52-61

[53] Liu R.M.: Down-regulation of y-glutamylcysteine synthetase regulatory subunit gene expression in rat brain tissue during aging. J. Neurosci. Res., 2002; 68: 344-351
[54] Pessayre D., Fromenty B., Berson A., Robin M.A., Lettéron P., Moreau R., Mansouri A.: Central role of mitochondria in drug-induced liver injury. Drug Metab. Rev., 2012; 44: 34-87

[55] Chen Y., Dong H., Thompson D.C., Shertzer H.G., Nebert D.W., Vasiliou V.: Glutathione defense mechanism in liver injury: Insights from animal models. Food Chem. Toxicol., 2013; 60: 38-44

[56] Chen Y., Yang Y., Miller M.L., Shen D., Shertzer H.G., Stringer K.F., Wang B., Schneider S.N., Nebert D.W., Dalton T.P.: Hepatocyte-specific Gclc deletion leads to rapid onset of steatosis with mitochondrial injury and liver failure. Hepatology, 2007; 45: 11181128

[57] McConnachie L.A., Mohar I., Hudson F.N., Ware C.B., Ladiges W.C., Fernandez C., Chatterton-Kirchmeier S., White C.C., Pierce R.H., Kavanagh T.J.: Glutamate cysteine ligase modifier subunit deficiency and gender as determinants of acetaminophen-induced hepatotoxicity in mice. Toxicol. Sci., 2007; 99: 628-636

[58] Jaeschke H., McGill M.R., Williams C.D., Ramachandran A.: Current issues with acetaminophen hepatotoxicity - a clinically relevant model to test the efficacy of natural products. Life Sci., 2011; 88: 737-745

[59] Pervaiz S., Clement M.V.: Tumor intracellular redox status and drug resistance-serendipity or a causal relationship? Curr. Pharm. Des., 2004; 10: 1969-1977

[60] Ballatori N., Krance S.M., Notenboom S., Shi S., Tieu K., Hammond C.L.: Glutathione dysregulation and the etiology and progression of human diseases. Biol. Chem., 2009; 390: 191-214

[61] Estrela J.M., Ortega A., Obrador E.: Glutathione in cancer biology and therapy. Crit. Rev. Clin. Lab. Sci., 2006; 43: 143-181

[62] Traverso N., Ricciarelli R., Nitti M., Marengo B., Furfaro A.L., Pronzato M.A., Marinari U.M., Domenicotti C.: Role of glutathione in cancer progression and chemoresistance. Oxid. Med. Cell. Longev., 2013; 2013: 972913

[63] Briehl M.M., Tome M.E., Wilkinson S.T., Jaramillo M.C., Lee K.: Mitochondria and redox homoeostasis as chemotherapeutic targets. Biochem. Soc. Trans., 2014; 42: 939-944

[64] Jang J.H., Surh Y.J.: Bcl-2 attenuation of oxidative cell death is associated with up-regulation of $\mathrm{Y}$-glutamylcysteine ligase via constitutive NF-KB activation. J. Biol. Chem., 2004; 279: 38779-38786

[65] Järvinen K., Soini Y., Kahlos K., Kinnula V.L.: Overexpression of $\mathrm{Y}$-glutamylcysteine synthetase in human malignant mesothelioma. Hum. Pathol., 2002; 33: 748-755

[66] Kim A.D., Zhang R., Han X., Kang K.A., Piao M.J., Maeng Y.H., Chang W.Y., Hyun J.W.: Involvement of glutathione and glutathione metabolizing enzymes in human colorectal cancer cell lines and tissues. Mol. Med. Rep., 2015; 12: 4314-4319

[67] Nguyen A., Loo J.M., Mital R., Weinberg E.M., Man F.Y., Zeng Z., Paty P.B., Saltz L., Janjigian Y.Y., de Stanchina E., Tavazoie S.F.: PKLR promotes colorectal cancer liver colonization through induction of glutathione synthesis. J. Clin. Invest., 2016; 126: 681-694

[68] Sun J., Zhou C., Ma Q., Chen W., Atyah M., Yin Y., Fu P., Liu S., Hu B., Ren N., Zhou H.: High GCLC level in tumor tissues is 
associated with poor prognosis of hepatocellular carcinoma after curative resection. J. Cancer., 2019; 10: 3333-3343

[69] Fiorillo M., Sotgia F., Sisci D., Cappello A.R., Lisanti M.P.: Mitochondrial "power" drives tamoxifen resistance: NQO1 and GCLC are new therapeutic targets in breast cancer. Oncotarget, 2017; 8: 20309-20327

[70] Hiyama N., Ando T., Maemura K., Sakatani T., Amano Y., Watanabe K., Kage H., Yatomi Y., Nagase T., Nakajima J., Takai D.: Glutamate-cysteine ligase catalytic subunit is associated with cisplatin resistance in lung adenocarcinoma. Jpn. J. Clin. Oncol., 2018; 48: 303-307

[71] Lin L.C., Chen C.F., Ho C.T., Liu J.J., Liu T.Z., Chern C.L.: $\mathrm{Y}$-Glutamylcysteine synthetase ( $\mathrm{Y}$-GCS) as a target for overcoming chemo- and radio-resistance of human hepatocellular carcinoma cells. Life Sci., 2018; 198: 25-31

[72] Liu C.W., Hua K.T., Li K.C., Kao H.F., Hong R.L., Ko J.Y., Hsiao M., Kuo M.L., Tan C.T.: Histone methyltransferase G9a drives chemotherapy resistance by regulating the glutamate-cysteine ligase catalytic subunit in head and neck squamous cell carcinoma. Mol. Cancer Ther., 2017; 16: 1421-1434

[73] Nowakowska A., Tarasiuk J.: Invasion and metastasis of tumour cells resistant to chemotherapy. Postępy Hig. Med. Dośw., 2017; 71: $380-397$

[74] Almusafri F., Elamin H.E., Khalaf T.E., Ali A., Ben-Omran T., El-Hattab A.W.: Clinical and molecular characterization of 6 children with glutamate-cysteine ligase deficiency causing hemolytic anemia. Blood Cells Mol. Dis., 2017; 65: 73-77

[75] Chen Y., Johansson E., Yang Y., Miller M.L., Shen D., Orlicky D.J., Shertzer H.G., Vasiliou V., Nebert D.W., Dalton T.P.: Oral $\mathrm{N}$-acetylcysteine rescues lethality of hepatocyte-specific Gclcknockout mice, providing a model for hepatic cirrhosis. J. Hepatol., 2010; 53: 1085-1094

[76] Rushworth G.F., Megson I.L.: Existing and potential therapeutic uses for $\mathrm{N}$-acetylcysteine: The need for conversion to intracellular glutathione for antioxidant benefits. Pharmacol. Ther., 2014; 141: 150-159

[77] Witschi A., Reddy S., Stofer B., Lauterburg B.H.: The systemic availability of oral glutathione. Eur. J. Clin. Pharmacol., 1992; 43: 667-669
[78] Levy E.J., Anderson M.E., Meister A.: Transport of glutathione diethyl ester into human cells. Proc. Natl. Acad. Sci. USA, 1993; 90: 9171-9175

[79] Du K., Ramachandran A., Jaeschke H.: Oxidative stress during acetaminophen hepatotoxicity: Sources, pathophysiological role and therapeutic potential. Redox Biol. 2016; 10: 148-156

[80] Quintana-Cabrera R., Fernandez-Fernandez S., Bobo-Jimenez V., Escobar J., Sastre J., Almeida A., Bolaños J.P.: Y-Glutamylcysteine detoxifies reactive oxygen species by acting as glutathione peroxidase-1 cofactor. Nat. Commun., 2012; 3: 718

[81] Chandler S.D., Zarka M.H., Vinaya Babu S.N., Suhas Y.S., Raghunatha Reddy K.R., Bridge W.J.: Safety assessment of gammaglutamylcysteine sodium salt. Regul. Toxicol. Pharmacol., 2012; 64: $17-25$

[82] Kobayashi H., Kurokawa T., Kitahara S., Nonami T., Harada A., Nakao A., Sugiyama S., Ozawa T., Takagi H.: The effects of gamma-glutamylcysteine ethyl ester, a prodrug of glutathione, on ischemia-reperfusion-induced liver injury in rats. Transplantation, 1992; 54: 414-418

[83] Le T.M., Jiang H., Cunningham G.R., Magarik J.A., Barge W.S., Cato M.C., Farina M., Rocha J.B., Milatovic D., Lee E. i wsp.: $\mathrm{\gamma}$-Glutamylcysteine ameliorates oxidative injury in neurons and astrocytes in vitro and increases brain glutathione in vivo. Neurotoxicology, 2011; 32: 518-525

[84] Yang Y., Li L., Hang Q., Fang Y., Dong X., Cao P., Yin Z., Luo L.: $Y$-glutamylcysteine exhibits anti-inflammatory effects by increasing cellular glutathione level. Redox Biol., 2019; 20: 157-166

[85] Salama S.A., Arab H.H., Hassan M.H., Al Robaian M.M., Maghrabi I.A.: Cadmium-induced hepatocellular injury: Modulatory effects of $y$-glutamyl cysteine on the biomarkers of inflammation, DNA damage, and apoptotic cell death. J. Trace. Elem. Med. Biol., 2019; 52: 74-82

[86] Salama S.A., Arab H.H., Maghrabi I.A., Hassan M.H., AlSaeed M.S.: Gamma-glutamyl cysteine attenuates tissue damage and enhances tissue regeneration in a rat model of lead-induced nephrotoxicity. Biol. Trace Elem. Res., 2016; 173: 96-107 